\title{
Morphoanatomy of Nothofagus alessandrii seeds and its use in the variability of populations
}

\section{Morfoanatomía de semillas de Nothofagus alessandrii y su uso en la variabilidad de poblaciones}

\author{
Rafael M ${ }^{a}$ Navarro-Cerrillo ${ }^{1 *}$, Rómulo Santelices ${ }^{2 *}$, Alberto Ruiz Rodríguez ${ }^{1}$, Angel Cabello \\ LECHUGA $^{3}$
}

1Departamento de Ingeniería Forestal, Escuela Técnica Superior de Ingenieros Agrónomos y de Montes, Universidad de Córdoba, Campus de Rabanales s/n, 14071 Córdoba, España.

2Departamento de Ciencias Forestales y Centro Tecnológico del Secano, Facultad de Ciencias Agrarias y Forestales, Universidad Católica del Maule, Casilla 617, Talca, Chile.

${ }^{3}$ Departamento de Silvicultura, Facultad de Ciencias Forestales, Universidad de Chile, Santa Rosa 11315, La Pintana, Santiago, Chile.

*rmnavarro@uco.es; *rsanteli@ucm.cl.

\begin{abstract}
Nothofagus alessandrii is an endangered species that is endemic to the Mediterranean area of Chile. There is no information on the anatomical structure of its seeds and there are few studies on the morphometric and germination differences between its populations. Therefore, the purpose of this study was to describe the morpho-anatomical structure of seeds of $N$. alessandrii in order to compare the morphology and germination four geographically distinct populations. This was done by selecting seeds of four different origins covering the entire latitudinal distribution of the species and measuring their size, shape, dry weight and germination in order to perform a comparative analysis. Results showed that the anatomical structure of $N$. alessandrii seeds is similar to that of other species of the Fagaceae family such as Fagus sylvatica. No differences were found between seeds from the four different origins in morphological characteristics or germinative power. Thus, it was not possible to demonstrate the existence of clinal variation, although the southernmost population showed differences in length and weight, suggesting that it may belong to a different ecotype.
\end{abstract}

KEYWORDS: Nothofagaceae, seed, ruil, germination, anatomy.

\section{RESUMEN}

Nothofagus alessandrii es una especie endémica del área Mediterránea de Chile, de la cual no se cuenta con información sobre la estructura anatómica de sus semillas. Existen muy pocos estudios sobre la variabilidad morfológica y de germinación entre sus poblaciones. El objetivo de este estudio fue describir la estructura morfoanatómica de semillas de $N$. alessandrii con el fin de comparar la morfología y la germinación entre cuatro poblaciones geográficamente separadas. Se seleccionaron semillas de cuatro orígenes geográficos a lo largo de la distribución latitudinal de la especie, y se midieron el tamaño, la forma, el peso seco, y la germinación. Los resultados mostraron que las semillas de $N$. alessandrii tienen una estructura anatómica similar a la de otras especies de la familia Fagaceae como Fagus sylvatica. No se encontraron diferencias significativas en las características morfológicas de los lotes estudiados, ni tampoco en el poder germinativo, por lo que no se ha observado una variación clinal entre poblaciones, aunque la población localizada más al sur presentó variaciones en longitud y peso, sugiriendo la posibilidad de ecotipo diferenciado.

Palabras Clave: Nothofagaceae, semilla, ruil, germinación, anatomía.

\section{INTRODUCTION}

Nothofagus alessandrii Espinosa (ruil) is a Chilean deciduous endemic species whose distribution is very restricted and fragmented along a strip of less than $100 \mathrm{~km}$ in the Cordillera de la Costa mountain range of the Maule Region between $35^{\circ}$ and $36^{\circ} \mathrm{S}$ (Olivares et al. 2005). The size of the remaining forest area where $N$. alessandrii occurs is 314 ha (Santelices et al. 2012); the species is only found on shaded slopes in mountainous areas at elevations 
from 150 to $500 \mathrm{~m}$ and forms mainly pure stands (Olivares et al. 2005, Rodríguez \& Quezada 2005, San Martín et al. 2006). The climate of the area of distribution of the species is a combination of Mediterranean climate with oceanic influences, with 5 to 6 arid months and 1 to 2 semi-arid months. The average temperature is $13.7^{\circ} \mathrm{C}$; maximum temperatures of $24.8^{\circ} \mathrm{C}$ are reached in January and a minimum temperatures $5.9^{\circ} \mathrm{C}$ are reached in July. Annual average rainfall is $830.7 \mathrm{~mm}$, with a peak of $186.4 \mathrm{~mm}$ in June (Di Castri \& Hajek 1976, San Martín \& Troncoso 1993). The soils where $N$. alessandrii grows usually have a moderately fine textured surface with good drainage. They are also characterized by their low fertility due to low phosphorus content and by being very weathered and thin, with very low water retention and susceptibility to erosion because of their old age and climatic influence (San Martín et al. 2006).

Although $N$. alessandrii forests represent a very distinctive ecosystem and the species is classified as Critically Endangered (UICN 2003), the surface covered by forests continues to decline mainly due to anthropogenic causes. Available information in the literature still focuses on aspects related to the ecology of the species and on its regeneration, although to a lesser extent (San Martín et al. 2006). Although histological studies have been globally reported for seeds of the Fagaceae family (Bonner \& Leak 2008), none of such studies have been reported on the anatomy of $N$. alessandrii seeds. Moreover, in contrast with other Nothofagus, no clinal variation has been found in the morphological characteristics of the reproductive and germination success of material of different origins (Santelices et al. 2009a).

The fruit is composed of several nuts, which are arranged from 3 to 7 within the dome $(3,5$, or 7$)$. The central nut is dimerous, flat, and flanked by two trimerous nuts. The four remaining nuts are dimerous or flat, smaller than the other ones and embedded in the inner supporting base of the valve; sometimes these nuts are not fully developed (Olivares et al. 2005, San Martín et al. 2006). Seeds start to mature in mid-January and dispersal takes place mainly in February (Olivares et al. 2005). The nuts are yellow-green in color and shortly winged (Olivares et al. 2005, San Martín et al. 2006). Each nut contains a single seed, filling all the space and is surrounded by a dry and hard pericarp. Because of the size of the wings, their dispersion is mainly by gravity (Olivares et al. 2005). The cotyledons are 15-20 mm long and 7-10 $\mathrm{mm}$ wide and are arranged in opposite positions, expanding outward (Olivares et al. 2005).

The seeds of $N$. alessandrii show some kind of physiological latency that has not been demonstrated yet (Olivares et al. 2005) despite the studies conducted on germination (Hechenleitner et al. 2005, Santelices et al. 2009b). These studies determined that cold stratification and immersion in gibberellic acid are suitable pre-germination treatments to obtain the best germination capacity.

Several studies have suggested that Nothofagus populations in Chile have high genetic variability (Donoso et al. 2006a, 2006b, 2006c). Smaller seed size and lower seed weight have been observed in southern populations. By contrast, germination capacity has been found to be higher in the most northern populations. This suggests the hypothesis that some Nothofagus species in Chile have a high degree of variability among populations. In the case of $N$. alessandrii, San Martín et al. (2006) mentioned the lack of studies showing genetic variations among different populations. However, Santelices et al. (2009a) obtained results that differed from other studies on Nothofagus species. They did not observe a significant clinal variation associated to five $N$. alessandrii origins. They noted that material from the southernmost origin tended to differ from the other ones, suggesting it may correspond to a different ecotype.

The selection of seed origin is very important in afforestation programs. In fact, the choice of the right origin is one of the main elements that determine the success and productivity of reforestation programs (Jara 1995). The scarcity of studies on $N$. alessandrii and the possible existence of different ecotypes justify the present study. The aim of our study was to explore the anatomical structure of seeds of $N$. alessandrii and the morphometric and germination differences between four geographically distinct populations of the species. In this latter aspect we intended to complement the work done by Santelices et al. (2009a). In other words, the purpose of this study was to perform a morph-anatomical study of $N$. alessandrii seeds to correlate the morphometric and germination capacity of four populations.

\section{MATERIAL AND METHODS}

\section{Plant Material AND STUdy AREA}

The seeds of $N$. alessandrii used in this study were collected from four different populations in February 2009 in the Maule Region of Chile (Table I). After being harvested and cleaned, they were sent to the seed laboratory of the School of Forestry Sciences of the University of Chile (April 2009). The seeds were cold-stored at $5^{\circ} \mathrm{C}$ throughout the entire process in rigid polyethylene bottles.

\section{MORPHO-PHYSIOLOGICAL CHARACTERISTICS OF SEEDS}

Based on the methodology proposed by Santelices et al. (2009a), the following morphological variables were measured in 5 repetitions of 15 seeds: length and width - in double-winged seeds, thickness was also measured using a $\mathrm{SOYODA}^{\circledR}$ caliper (error $\pm 0.05 \mathrm{~mm}$ ).

Seed tests were performed according to ISTA standards (ISTA 2006) and particularly involved determining the 
weight and moisture content of one thousand seeds. Additionally, viability was estimated using a cut test. For each batch of seeds, 4 replications of 100 seeds each were weighed on a four-digit precision balance (Denver Instrument Company $\left.{ }^{\circledR}, A A-200\right)$. The determination of moisture content was performed on the selected samples for the viability test, considering each of the repetitions of 15 seeds of each lot. Seeds were first weighed to determine their wet weight (WW) and then placed in a forced air oven (WTB Binder) at $105^{\circ} \mathrm{C}$ for $17 \mathrm{~h}$, until their weight was constant. Once the drying period was finished, seed dry weight (DW) was calculated by weighing them again on the same balance. Seed moisture content (MC) was calculated using the following expression:

$$
\mathrm{MC}(\%)=\frac{\mathrm{WW}-\mathrm{DW}}{\mathrm{WW}} * 100
$$

A germination test was conducted for each origin based on a cold stratification treatment at $5^{\circ} \mathrm{C}$ for 30 days plus a control treatment. Each test included three replications of 25 seeds each (ISTA 2006). In both treatments, the seeds were soaked prior to the test for $24 \mathrm{~h}$ at room temperature; seeds that floated were rejected. Stratification was performed by mixing the seeds with wet sand and distilled water previously sterilized at $150^{\circ} \mathrm{C}$ for $2 \mathrm{~h}$. Subsequently, the seeds were packed in labeled plastic bags and left for 30 days at $5^{\circ} \mathrm{C}$. After the pre-germination treatment, the seeds were placed in Petri dishes using filter paper as substrate. The capsules were covered with black polythene to prevent light exposure and excessive moisture loss. They were kept at $20^{\circ} \mathrm{C}$ during the 31 days of the test in a growth chamber $\left(\right.$ TRILAB $^{\circledR}$ ); seeds were considered to have germinated when the radicle emerged ( $>1 \mathrm{~mm}$ in length). The effectiveness of the treatments applied to the seeds was determined by measuring their germinating power, that is, the accumulated percentage of germinated seeds at the end of the test.

The analysis of variance and mean comparisons were conducted using the General Linear Model procedure of the SPSS statistical program for Windows ${ }^{\circledR}$ version 15.0. The Bliss angular transformation $\left(\mathrm{y}^{\prime}=\operatorname{arcoseno} \sqrt{\mathrm{p}}\right)$ was applied before performing the analysis in order to normalize the variables expressed in percentages. Average values showing significant differences were compared with the Tukey test at $5 \%$ level.

DesCription OF THE TISSUE STRUCTURE OF THE SEED

The seeds used in the experiment were previously prepared by removing the seed coat (Figs. 1b, 1c). A sample containing non-germinated seeds and sprouts was selected and subjected to small transverse incisions to facilitate infiltration of the fixative solution. The cuts were made in one of the lateral sections, always cutting off areas that were not to be used for the histological cuts. Subsequently, we followed the methodology proposed by Ruzin (1999) for fixing, processing, and obtaining the histological cuts. The cuts were made with a rotary microtome (E. Leitz Wetzlar ${ }^{\mathbb{R}}$, Germany) that produced sections $11 \mu \mathrm{m}$ thick. During the assembly of the samples on the microscope slides, they were first covered with a drop of Mayer glue (egg white, glycerin and sodium silicate). Next, with the slide partly submerged in the hot water dish and with the assistance of a punch, a strip of paraffin was placedon the slides, which were placed in the right position before bringing them completely out of the water. The slide -with the paraffin strip on it- was dried at room temperature on wooden trays. The cuts were stained following the methodology described by Jensen (1962), using a combination of tannic acid, ferric chloride $\left(\mathrm{FeCl}_{3}\right)$, safranin and fast green. Once the staining was completed, we proceeded to final assembly. We added a few drops of Floo-Tex on the samples and then the cover slips were placed on the stained preparations. The cuts were observed with a confocal microscope (TCS-SP2Spectral AOBS, Leica ${ }^{\circledR}$ ) owned by the research support service (Servicio Central de Apoyo a la Investigación, SCAI) of the University of Cordoba (Spain). The images were captured on a computer thanks to a digital camera attached to the microscope and analyzed following the procedure described by Bonner \& Leak (2008) for seeds of the Fagaceae family (Fig. 1a).

TABLE I: Geographical location and climatic conditions (Santibáñez \& Uribe 1993) of the origins of the plant material of Nothofagus alessandrii used in this study.

TABLA I: Localización geográfica y condiciones climáticas (Santibáñez \& Uribe 1993) de los orígenes del material de Nothofagus alessandrii usado en este estudio.

\begin{tabular}{lccccc}
\hline Origins & $\begin{array}{c}\text { Latitude } \\
(\mathrm{S})\end{array}$ & $\begin{array}{c}\text { Length } \\
(\mathrm{O})\end{array}$ & $\begin{array}{c}\text { Altitude } \\
(\mathrm{m})\end{array}$ & $\begin{array}{c}\text { Annual MEAn } \\
\text { RAinfall }(\mathrm{mm})\end{array}$ & $\begin{array}{c}\text { Annual MEAn } \\
\text { TemperatuRe }\left({ }^{\circ} \mathrm{C}\right)\end{array}$ \\
\hline Huelón Alto & $35^{\circ} 05^{\prime}$ & $72^{\circ} 04^{\prime}$ & 230 & 708 & 13,1 \\
Lo Ramírez & $35^{\circ} 10^{\prime}$ & $72^{\circ} 06^{\prime}$ & 385 & 708 & 13,1 \\
Empedrado & $35^{\circ} 40^{\prime}$ & $72^{\circ} 19^{\prime}$ & 300 & 926 & 13,3 \\
R.N. Los Ruiles & $35^{\circ} 50^{\prime}$ & $72^{\circ} 30^{\prime}$ & 280 & 837 & 11,7 \\
\hline
\end{tabular}



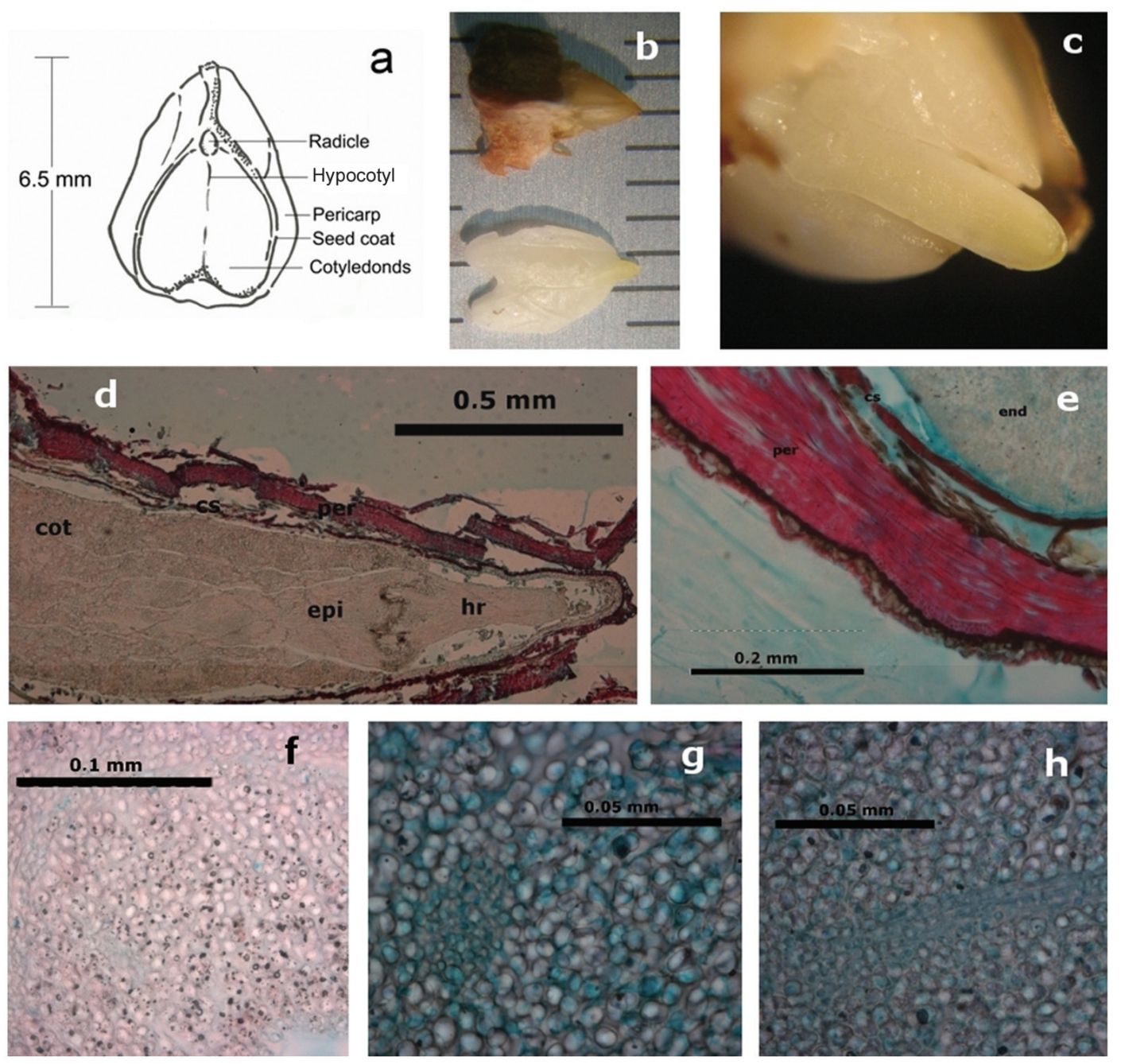

Figure 1: Overview of N. alessandrii seed showing details of the different structures. a: longitudinal section of a Fagus grandiflora seed (Source: Bonner \& Leak, 2008); b: seed stripped of the different external layers, c: fresh longitudinal cut of the embryo; d: longitudinal section of a mature seed, showing pericarp (per), seed coat (sc), cotyledons (cot) and epicotyl (epi) hypocotyl-radicle axis (hr) e: Cross section of testa showing the endosperm (end), the seed coat (sc) covering it and the different layers constituting the pericarp (per), f: detail of the ergastic substances (dark spots) present in the cells forming the cotyledons, g: cross section of vascular bundle within the cotyledons, $\mathrm{h}$ : longitudinal section of the vascular bundle within the cotyledons.

Figura 1: Vista de una semilla de N. alessandrii mostrando los detalles de las diferentes estructuras: a: sección longitudinal de una semilla de Fagus grandiflora (Bonner \& Leak, 2008); b: corte de una semilla mostrando las diferentes cubiertas, c: corte fresco longitudinal del embrión; d: sección longitudinal de una semilla madura mostrando el pericarpio (per), cubierta seminal (sc), cotiledones (cot) y eje hipocotilo-radícula (hr) e: sección de la testa mostrando el endospermo (end), la cubierta seminal (sc) y las diferentes capas que forman el pericarpio (per), f: detalles de las sustancias ergásticas (puntos oscuros) presentes en las células que forman los cotiledones, g: sección de haces vasculares dentro de los cotiledones, h: sección longitudinal de los haces vasculares dentro de los cotiledones.

\section{RESULTS}

SEED MORPHOLOGY

The fruit is composed of 5 to 7 nut-like dry and indehiscent seeds. Mature seeds are light brown, oblong in shape, elongated, more or less angular, and frequently asymmetric in their main axis (Fig. 1). Seeds are clearly compressed, often with two lateral wings (Fig. 1). The surface pattern (primary ornamentation) of the seed is slightly striate, with slightly prominent outer walls that are curved or sinuate as a result of drying. Seed measures were related to seed type: trimerous seeds were 6.1 to $6.5 \mathrm{~mm}$ long by 4.5 to 5.0 $\mathrm{mm}$ wide, and dimerous seeds were 6.4 to $6.7 \mathrm{~mm}$ long by 4.2 to $4.4 \mathrm{~mm}$ wide (Table II). Significant differences were obtained in all morphological parameters both for dimerous and trimerous $N$. alessandrii seeds according to the one-way 
ANOVA $(\mathrm{P}<0.01)$ (Table II). It is worth noting the origin of R.N. Los Ruiles, which showed the highest values in the size of dimerous seeds, and the Empedrado origin, which showed the highest values in the size of trimerous seeds.

The general structure of the seed is shown in Figure 1d in a section parallel to the longitudinal plane, where the main elements forming the nucule can be seen: a thin and hardened pericarp and an embryo occupying practically the totality of the seed. Seeds of $N$. alessandrii have a pericarp derived from the ovary surrounding and protecting it. At maturity, the pericarp has a smooth, light brown surface and is composed of sclerified cells, particularly fibers arranged perpendicular to the cut on the outside and parallel to it on the inside. Cells have thick walls, a narrow lumen and simple pits (Fig. 1e). The pericarp mainly surrounds the embryo because $N$. alessandrii seeds are not endospermic at maturity, as a result of the complete consumption of this tissue by the embryo during the growing and developing period and the conversion of the cotyledons into storage organs. There is a seed coat or very thin testa between the embryo and the pericarp, and it is composed of several layers (Fig. 1e). Although the seed coat is slightly split up, the cells are clearly distinct, with thin dark brown color walls that appear to be composed of flattened cells impregnated with tannins. The testa is derived from the integuments of the ovule. There is also a thin-walled parenchymatous tissue attached to the testa (Fig. 1d).

TABLE II: Morphologic characteristics of the Nothofagus alessandrii seeds from the different origins (media \pm standard error).

TABLA II: Características morfológicas de las semillas de Nothofagus alessandrii, de los diferentes orígenes (media \pm error estándar).

\begin{tabular}{|c|c|c|c|c|c|}
\hline \multirow[t]{3}{*}{ ORIGIN } & \multicolumn{5}{|c|}{ SEed SIZE $(\mathrm{mm})$} \\
\hline & \multicolumn{3}{|c|}{ TRIMEROUS } & \multicolumn{2}{|c|}{ DIMEROUS } \\
\hline & LENGTH & WIDTH & THICKNESS & LENGTH & WIDTH \\
\hline Huelón Alto & $6.1 \pm 0.09 \mathrm{~b}$ & $4.8 \pm 0.06 \mathrm{ab}$ & $1.2 \pm 0.02 \mathrm{ab}$ & $6.4 \pm 0.07 b$ & $4.4 \pm 0.07 \mathrm{a}$ \\
\hline Lo Ramírez & $6.4 \pm 0.08 \mathrm{ab}$ & $4.5 \pm 0.10 \mathrm{~b}$ & $1.2 \pm 0.03 \mathrm{ab}$ & $6.4 \pm 0.06 b$ & $4.2 \pm 0.07 \mathrm{ab}$ \\
\hline Empedrado & $6.4 \pm 0.10 \mathrm{ab}$ & $4.6 \pm 0.10 b$ & $1.2 \pm 0.03 \mathrm{ab}$ & $6.7 \pm 0.09 \mathrm{a}$ & $4.2 \pm 0.07 \mathrm{a}$ \\
\hline R.N. Los Ruiles & $6.5 \pm 0.11 \mathrm{a}$ & $5.0 \pm 0.12 \mathrm{a}$ & $1.3 \pm 0.03 \mathrm{ab}$ & $6.4 \pm 0.08 \mathrm{~b}$ & $4.4 \pm 0.06 \mathrm{a}$ \\
\hline
\end{tabular}

Mean values with the same letter do not significantly differ from each other, $P \leq 0.05$ / Valores medios seguidos de la misma letra no son estadísticamente diferentes $P \leq 0.05$.

Seeds have a terminal hilum, and seed disposition is symmetric from hilum and rarely laterally displaced. The hilum is rounded, the micropyle is obscure and a vascular bundle traverses the raphe, extending to the chalaza. The whitish embryo is composed of two thin plano-convex and wrinkled cotyledons: the epicotyl and hypocotylradicle axis, where is not possible to clearly distinguish the transition between the hypocotyl and the radicle (Fig. 1c). As $N$. alessandrii seeds are dicotyledons, erefore the embryo is formed by an embryonic axis and the first two leaf structures. The embryo axis is located between the cotyledons in the apical zone of the seed and is formed by the hypocotyl-radicle axis and the epicotyl. The cotyledons are thin and very wrinkled, occupying almost the entire nut. According to their function as storage organs, they contain ergastic substances that are used by the embryo during its germination and later by the plant during its early developmental stages, until functional leaves can produce photosynthesis. They have relatively homogeneous parenchyma inside that function as storage and consist of several layers of thin-walled polyhedral cells filled with various ergastic substances, notably starch grains (Fig. 1f). The starch grains, made up of insoluble carbohydrates (polysaccharides complex), are the most common storage materials found. Starch is commonly accumulated in the form of different types of starch grains with a shiny refractive point, which is the starting area of active growth. Starch grains have simple concentric shapes; some of them are spherical and others are oval-shaped. The cotyledons have a vascular system that mobilizes the reserve substances into the functional tissues (Figs. 1g, 1h).

The embryo axis is located in the apex zone inside the seed, on the opposite side where the dome is inserted. Their entire structure is shown in Figure 1d, where the hypocotyl-radicle axis can be distinguished. At its basal end, the embryo axis has an incipient radicle formed mostly by meristematic tissue and covered by the root cap, which is a conical coverage surrounding the root apex that is not visible to the naked eye and consists of soft undifferentiated tissue formed by live parenchyma cells. The root cap covers the meristematic tissue protecting it and providing mechanical protection to the meristematic cells as the roots 
grows through the soil. The hypocotyl is the portion of the embryonic axis that is below the insertion point of the cotyledons, the cotyledonary node and the radicle above. Due to the nature of the embryo of $N$. alessandrii, it is not easy to distinguish between the structures of the radicle and the hypocotyl. This is why the group is called the hypocotylradicle axis. The epicotyl, a promeristem that also consists of of meristematic tissue, is found at the apical end of the embryonic axis, above the cotyledonary node; this is the place from which the stem of the plant will develop.

\section{SEed AnALYsis}

Table III shows the analysis of seeds from the four different origins. Laboratory germination began after 7 days in the incubator; $\mathrm{T}_{50}$ was completed within 11-14 days and essentially finished within 21-24 days (data not included). The moisture content of the seeds at maturity varied between
7.0 and $9.0 \%$ and the weight of 1000 seeds ranged from 9.0 to $10.8 \mathrm{~g}$. Although significant differences were found for both variables, moisture content was found to be a more variable parameter among origins.

Control seeds of some origins almost failed to germinate (RN Los Ruiles, 1.3\%) whereas those of other origins had a high germination percentage (Lo Ramirez, 21.3\%). Chilling of the intact fruits increased the germination percentage, although the level of germination at the end of the experiment was variable among origins (RN Los Ruiles $34.7 \%$ to Lo Ramirez $69.3 \%$ ); seeds from the southernmost origin showed the lowest germination values. The one-way ANOVA of germination percentage showed a significant effect of the stratification treatment $(P<0.001)$. Seed viability was not consistent with germination, as seeds from the Empedrado origin showed the highest value (60\%), with significant differences among origins as well.

TABLE III: Seed analysis of Nothofagus alessandrii seeds from the different origins (media \pm standard error).

TABLA III: Análisis de semillas de Nothofagus alessandrii, de los diferentes orígenes (media \pm error estándar).

\begin{tabular}{|c|c|c|c|c|c|}
\hline \multirow{2}{*}{ ORIGIN } & \multirow{2}{*}{$\begin{array}{l}\text { WeIGHT OF } 1000 \\
\text { SEEDS }(\mathrm{g})\end{array}$} & \multirow{2}{*}{$\begin{array}{c}\text { MOISTURE CONTENT } \\
(\%)\end{array}$} & \multirow{2}{*}{ VIABILITY (\%) } & \multicolumn{2}{|c|}{ GERMINATION CAPACITY (\%) } \\
\hline & & & & E30 & Control \\
\hline Huelón alto & $10.1 \pm 2.3 \mathrm{a}$ & $7.0 \pm 0.15 b$ & $21.3 \pm 6.7 \mathrm{~b}$ & $62.7 \pm 4.1 \mathrm{a}$ & $9.3 \pm 4.8 \mathrm{ab}$ \\
\hline Lo Ramírez & $9.0 \pm 1.5 b$ & $7.4 \pm 0.38 \mathrm{ab}$ & $34.7 \pm 4.2 \mathrm{ab}$ & $69.3 \pm 1.7 \mathrm{a}$ & $21.3 \pm 3.5 \mathrm{a}$ \\
\hline Empedrado & $10.3 \pm 3.1 \mathrm{a}$ & $7.7 \pm 0.89 \mathrm{ab}$ & $60.0 \pm 4.0 \mathrm{a}$ & $58.7 \pm 2.9 \mathrm{a}$ & $6.7 \pm 2.7 \mathrm{ab}$ \\
\hline R.N. Los Ruiles & $10.8 \pm 1.6 \mathrm{a}$ & $9.0 \pm 0.09^{\mathrm{a}}$ & $38.7 \pm 3.0 \mathrm{ab}$ & $34.7 \pm 1.6 b$ & $1.3 \pm 1.3 b$ \\
\hline
\end{tabular}

$\mathrm{E} 30=$ stratification for 30 days. Mean values with the same letter do not significantly differ from each other, $P \leq 0.05 /$

Estratificación por 30 días. Valores medios seguidos de la misma letra no son estadísticamente diferentes $P \leq 0.05$.

\section{DISCUSSION}

In this study we described the morphology and anatomy of $N$. alessandrii seed and compared the morphometric and germination variation of four geographically distinct populations.

The anatomical characteristics of Nothofagus resemble those described for similar genera such as Fagus or Quercus (Ledgard \& Cath 1973, León-Lobos \& Ellis 2005, Cinar-Yilmaz \& Akkemik 2007, Bonner \& Leak 2008). Morphological and anatomical studies of the Fagaceae family have globally described the anatomy of its seeds (Kirkbride et al. 2006). However, the internal structure of $N$. alessandrii seeds has been not studied so far. Although the fruits and morphological structure of these seeds have been superficially described (Olivares et al. 2005; San Martín et al.
2006), no histological studies have described their anatomy in detail. $N$. alessandrii seeds have a general structure that consists of a hard sclerified pericarp, a very thin seed coat and an embryo with two wrinkled cotyledons -occupying almost the entire volume of the seed- and an embryonic axis at the apex zone of the seed, where the epicotyl and hypocotyl-radicle axis can be differentiated (Kirkbride et al. 2006). The pericarp is smooth, light brown and composed of sclerified cells and fibers arranged in different layers, which give better resistance to this protective layer of the seed. Between the pericarp and embryo there is a thin seed coat or testa; its color suggests that it is formed by flattened cells impregnated with tannins, although it was not possible to confirm this. It would therefore be advisable to verify this in future research with histochemical studies. There is also a thin-walled parenchymatous tissue attached to the testa. 
This histochemistry may be related to the ecophysiological and protective response of $N$. alessandrii seeds. We noted the absence of Perzelia sp. damage on $N$. alessanddrii seeds in contrast to those of other Nothofagus species (Santelices, R. personal observation); although it can be derived from this study.

It is possible that they are remains of nucellus or endosperm, though it is not possible to affirm either, therefore it would be convenient in the future to make further cuts in the various stages of embryo development. The last part of the seed -the embryo- consists of the cotyledons and the embryonic axis. Seeds of $N$. alessandrii have two thin and much wrinkled cotyledons, which occupy almost the entire nut. The cotyledons consist of storage parenchyma formed by polyhedric cells of thin walls with ergastic substances inside. The starch grains are the most common reserve materials found in $N$. alessandrii seeds. Starch is commonly accumulated in the form of different types of starch grains that are stored by amyloplasts (leucoplasts). Layers of starchy materials are deposited around the hilum, representing lines of stratification (Stern 1994). The hilum also has a vascular system to mobilize the storage substances towards the points with major meristematic activity. The embryonic axis is located in the apical zone of the inner part of the seed and consists of the epicotyl and hypocotylradicle axis, whose name is due to the inability to differ between the hypocotyl and the radicle.

The morphometric analysis parameters studied in seeds of the five origins revealed that, although there were significant differences in seed size (length, width and thickness) among origins, none of the parameters could be related with latitude variation. This is in contrast with other species of Nothofagus (Donoso et al. 2006a, 2006b, 2006c). Considering the results of the morphometric analysis, we can conclude that seed size is relatively homogeneous, as noted in former studies (Olivares et al. 2005, Santelices et al. 2009a). As stated by Santelices et al. (2009a), it was not possible to associate any increase or decrease in seed size with the differences in latitude of the different origins of the seeds, in contrast with other species of Nothofagus (Donoso et al. 2006a; Donoso et al. 2006b, Donoso et al. 2006c). This may be due to the limited and fragmented distribution of the species (Olivares et al. 2005). The small range of $N$. alessandrii is exceptional compared to the rest of Chilean Nothofagus, which have larger ranges throughout the country, leading to a reduced but significant latitudinal variation in Nothofagus nervosa (Phil.) Dim et Mil., Nothofagus dombeyi (Mirb.) Oerst. and Nothofagus obliqua (Mirb.) Oerst. (Donoso et al. 2006a, 2006b, 2006c). Still, it is worth mentioning that the southernmost origin (R.N. Los Ruiles) showed significant differences from the other populations, with a larger size, which was consistent with that observed by Santelices et al. (2009a).

Although significant differences were found between origins in seed germination and viability, as in the morphometric results it was not possible to establish a relationship with latitudinal variation. It should be noted that the highest percentage of viable seeds were from the Empedrado origin (61.3\%). There may be a relationship between seed diameter and seed viability and germination capacity. The highest germination power and seed size values were found in seeds from the Empredrado origin. The result range obtained for the seed batches expressed through seed weight (9.0 and $10.8 \mathrm{~g}$ per 1000 seeds) is consistent with the results obtained by several authors (Acuña 2001, Donoso and Cabello 1978). Seeds from the southernmost origin (R.N. Los Ruiles) had the lowest weight, which can be explained by the high moisture content of seeds from this batch. Although seed weight values showed significant differences between the origins studied, as in the morphometric results it was not possible to observe any relationship between weight and latitudinal variation of origins (Santelices et al. 2009a). Still, this result is not so surprising since Olivares et al. (2005) indicated that seeds of $N$. alessandrii may present very low weights, reaching values of 76,209 seeds $\mathrm{kg}^{-1}$. The low water content and weight of the seeds indicate that $N$. alessandrii seeds are very close to the area of orthodox seeds in the scheme proposed by Hong \& Ellis (1996).

The germination test of the present study, which analyzed parameters of the germinative vigor of the seed in two different treatments, was used to determine the positive effect of cold stratification on germination. It can be concluded that cold stratification of $N$. alessandrii seeds increases their germinative vigor. The results confirm something that has been well-documented for the genus: the large number of Nothofagus species whose seeds have internal dormancy (Donoso \& Cabello 1978, Donoso et al. 2006a, 2006b, 2006c), which obviously limits germination success. Dormancy phenomena justify applying cold stratification to seeds, which removes the concentration of inhibitors and thus promotes germination (Baskin and Baskin 1998). Differences of germination power among the different origins were also significant; yet, not relationship was found with latitude, unlike other species of Nothofagus such as $N$. nervosa (Donoso et al. 2006c), N. dombeyi (Donoso et al. 2006b) or N. obliqua (Donoso et al. 2006a). This lack of correlation between latitudinal range and the germination rate of $N$. alessandrii seeds is consistent with the results obtained by Santelices et al. (2009a). The best germination rates were obtained with the cold stratification treatment at $5^{\circ} \mathrm{C}$ for 30 days. The origin that obtained the best results was Lo Ramírez, reaching $69.3 \%$ of germinated seeds. This origin also differed in the control treatment. The origin that obtained the worst results was R.N. Los Ruiles, reaching only $34.7 \%$ of germinated seeds; it also differed from the others in the control treatment, but with lower values. These results are comparable to those obtained by 
Santelices et al. (2009a), which also found the worst results with the Cauquenes origin (R.N. Los Ruiles), and very good results with the Lo Ramírez origin.

The morphological variables studied did not show any significant relationships between seed size and the latitudinal position of the populations where the seeds came from, just like other Nothofagus species. Still, one of the origins -R.N. Los Ruiles (in the southeast) - differed significantly from the others, with larger seeds. No significant relationships were found between latitudinal variation and viability or between latitude and seed weight. Seeds of $N$. alessandrii responded very well to cold stratification (31 days with a temperature of $5^{\circ} \mathrm{C}$ ) which significantly improved seed germination.

\section{ACKNOWLEDGMENTS}

This study was supported by a $\mathrm{PhD}$ cooperation program between the University of Cordoba, the University of ChileCatholic University of Maule and the Chagual Botanic Garden. We are especially grateful to Dr. Adelina Manríquez for use of Plant Anatomy facilities. Additional thanks are due to project DIVERBOS-CGL2011-30285-C02-02.

\section{REFERENCES}

ACUÑA, M. 2001. Formulación de un protocolo de trabajo para el análisis de semillas de especies leñosas nativas. Memoria de Ingeniero Forestal. Universidad de Chile, Santiago, Chile. 87 pp.

BASkin, C.C. \& J.M. Baskin. 1998. Seeds. Ecology, Biogeography, and Evolution of Dormancy and Germination. Academic Press, San Diego, USA. 666 p.p.

Bonner, F.T. \& W.B. Leak. 2008. Fagus L. beech. In: F.T. Bonner \& R.P. Karfalt (eds.), The woody plant seed manual, pp. 520-524. Handbook 727, U.S. Department of Agriculture, Washington, USA.

Cinar-Yilmaz, H. \& U. Akkemik. 2007. Embryo anatomy in Quercus alnifolia Poech. Seed Science and Technology, 35: 494-496.

Di Castri, F. \& E. Hajek. 1976. Bioclimatología de Chile. Imprenta-Editorial de la Universidad Católica de Chile, Santiago de Chile. 129 pp.

Donoso, C. \& A. Cabello. 1978. Antecedentes fenológicos y de germinación de especies leñosas chilenas. Ciencias Forestales 1: 31-40.

Donoso, P., C. Donoso, L. Gallo, M. Azpilicueta, A. Baldini \& B. Escobar. 2006a. Nothofagus obliqua (Mirb.) Oerst. Roble, Pellín, Hualle. En: C. Donoso (ed). Las especies arbóreas de los bosques templados de Chile y Argentina, autoecología, pp 471-485. Marisa Cuneo Ediciones, Valdivia, Chile.

Donoso, P., C. Donoso, L. Gallo, C. Navarro \& B. Escobar. 2006b. Nothofagus dombeyi (Mirb.) Oerst. Coihue, Coigüe. Familia Fagaceae. En: C. Donoso (ed.), Las especies arbóreas de los bosques templados de Chile y Argentina, autoecología, pp 423-432. Marisa Cuneo Ediciones, Valdivia, Chile.

Donoso, P., P. Marchelli, C. Donoso, L. Gallo \& B. Escobar. 2006c. Nothofagus nervosa (Phil.) Dim. et Mil. Otros nombres científicos usados: Nothofagus alpina, Nothofagus procera. Raulí. En: C. Donoso (ed), Las especies arbóreas de los bosques templados de Chile y Argentina, autoecología, pp 448-461. Marisa Cuneo Ediciones, Valdivia, Chile.

Hechenleitner, P., M. Gardner, P. Thomas, C. Echeverría, B. Escobar, P. Brownless \& C. Martínez. 2005. Plantas amenazadas del centro-sur de Chile. Distribución, conservación y propagación. Universidad Austral de Chile \& Real Jardín Botánico de Edimburgo, Valdivia, Chile. $188 \mathrm{pp}$.

Hong, T.D. \& R.H. Ellis. 1996. A protocol to determine seed storage behavior. Notes International Plant Genetic Resources Institute. Department of Agriculture, The University of Reading, UK 62 pp.

ISTA2006. International Rules for Seed Testing. ISTA(International Seed Testing Association), Zurich, Switzerland. 70 pp.

JARA, L. 1995. Mejoramiento forestal y conservación de recursos genéticos forestales. Tomo I. Manual técnico $\mathrm{N}^{\circ} 14$. CATIE, Turrialba, Costa Rica. 174 pp.

Jensen, W.A. 1962. Botanical Histochemistry. W.H. Freeman and Co., San Francisco, USA. 408 pp.

Kirkbride, J.H. (JR.), C.R. Gunn \& M.J. Dallwitz. 2006. Family guide for fruits and seeds, vers. 1.0. URL: http://nt.arsgrin.gov/sbmlweb/OnlineResources/frsdfam/Index.cfm, Viewed: December 16, 2010.

LANGDOM, L.M., 1939. Ontogenetic and anatomical studies of the flower and fruit of the Fagaceae and Juglandaceae. Botanical Gazette 101: 301-327.

Ledgard, N.J. \& P.W. Cath. 1973. Seed of New Zealand Nothofagus Species: Studies of seed weight, viability, shape and the effect of varying stratification. New Zealand Journal of Forestry 28: 150-162.

Leon, P. \& R.H. Ellis. 2005. Seed survival in Chilean Nothofagus in response to desiccation and storage. Seed Science Research 15: 113-123.

Olivares, P., J. San Martín \& R. SAntelices. 2005. Ruil (Nothofagus alessandrii): Estado del conocimiento y desafíos para su conservación. Comisión Nacional del Medioambiente (CONAMA), Talca, Chile. 55 pp.

Rodríguez, R. \& M. QuezadA. 2005. Fagaceae. En: C. Marticorena \& R. Rodríguez, Flora de Chile, Volumen 2, Fascículo 3: Plumbaginaceae-Malvaceae, pag. 64-76. Ediciones Universidad de Concepción Chile.

Ruzin, S.E. 1999. Plant Microtechnique and Microscopy. Oxford University Press, Science, 322 pp.

San Martín, J. \& A. Troncoso. 1993. Especies de Nothofagus (Fagaceae) en la depresión intermedia de la $7^{\text {a }}$ Región (Chile Central). Bosque 1: 37-44.

San Martín, J., R. Santelices \& R. Henríquez. 2006. Nothofagus alessandrii Espinosa, Ruil. Familia: Fagaceae. En: C. Donoso (ed.), Las especies arbóreas de los bosques templados de Chile y Argentina, autoecología, pp 390-400. Marisa Cuneo Ediciones, Valdivia, Chile.

Santelices, R., R.M. Navarro-Cerrillo \& F. Drake. 2009a. 
Caracterización del material forestal de reproducción de cinco procedencias de Nothofagus alessandrii Espinosa una especie en peligro de extinción. Interciencia 34: 113119.

Santelices, R., R.M. Navarro-Cerrillo \& F. Drake. 2009 b. Propagation and seedling cultivation of the endemic species Nothofagus alessandrii Espinosa in Central Chile. Restoration Ecology 19: 177-185.

Santelices, R., F. Drake, C. Mena, R. Ordenes \& R.M. NavarroCERriLlo. 2012. Current and potential distribution areas for Nothofagus alessandrii, an endangered tree species from central Chile. Ciencia e Investigación Agraria 39: 521-531.

SantibÁñez, F. \& J. Uribe. 1993. Atlas agroclimático de Chile, regiones VI, VII, VIII y IX. Ediciones de la Universidad de Chile, Santiago de Chile. 99 pp.

Stern, K.H.1994. Plant Biology. 6th ed., Wm. C. Brown. Co. Inc., Dubuque.

UICN. 2003. Categorías y criterios de la lista roja de la UICN: Versión 3.1. Comisión de Supervivencia de Especies de la UICN, Gland, Switzerland \& Cambridge, UK. 33 pp.

Recibido: 23.07.12

Aceptado: 22.03.13 